\title{
TU/e EmonOWEN

\section{Sodium sulfate salt weathering of porous building materials studied by NMR}

\section{Citation for published version (APA):}

Saidov, T. A., Pel, L., \& Kopinga, K. (2017). Sodium sulfate salt weathering of porous building materials studied by NMR. Materials and Structures, 50(2), 1-11. [145]. https://doi.org/10.1617/s11527-017-1007-9

\section{Document license:}

TAVERNE

DOI:

10.1617/s11527-017-1007-9

Document status and date:

Published: 01/04/2017

\section{Document Version:}

Publisher's PDF, also known as Version of Record (includes final page, issue and volume numbers)

\section{Please check the document version of this publication:}

- A submitted manuscript is the version of the article upon submission and before peer-review. There can be important differences between the submitted version and the official published version of record. People interested in the research are advised to contact the author for the final version of the publication, or visit the $\mathrm{DOI}$ to the publisher's website.

- The final author version and the galley proof are versions of the publication after peer review.

- The final published version features the final layout of the paper including the volume, issue and page numbers.

Link to publication

\section{General rights}

Copyright and moral rights for the publications made accessible in the public portal are retained by the authors and/or other copyright owners and it is a condition of accessing publications that users recognise and abide by the legal requirements associated with these rights.

- Users may download and print one copy of any publication from the public portal for the purpose of private study or research.

- You may not further distribute the material or use it for any profit-making activity or commercial gain

- You may freely distribute the URL identifying the publication in the public portal.

If the publication is distributed under the terms of Article 25fa of the Dutch Copyright Act, indicated by the "Taverne" license above, please follow below link for the End User Agreement:

www.tue.nl/taverne

Take down policy

If you believe that this document breaches copyright please contact us at:

openaccess@tue.nl

providing details and we will investigate your claim. 


\title{
Sodium sulfate salt weathering of porous building materials studied by NMR
}

\author{
Tamerlan A. Saidov $[$ - Leo Pel $\cdot$ Klaas Kopinga
}

Received: 21 June 2016/Accepted: 30 January 2017/Published online: 1 March 2017

(C) RILEM 2017

\begin{abstract}
Sodium sulfate is known as one of the most destructive salts causing weathering. Many experiments on accelerated weathering tests show that major deterioration effects by weathering are caused by drying and wetting cycles of porous materials saturated with salt solution. In this study we have performed accelerated weathering tests with sodium sulfate in common building materials (firedclay brick, Indiana limestone and Cordova limestone) measuring the concentration in the materials simultaneously with their expansion. The concentration of sodium sulfate solution is measured non-destructively using Nuclear Magnetic Resonance, while the expansion of the sample caused by crystal growth is measured with a fiber optic displacement sensor. The simultaneous measurement of solution concentration within a material and expansion allow assessment of crystallization pathways most responsible for damage during weathering, i.e., cycles of wetting and drying. It was shown by direct observation, that with rewetting of the partially dried samples, the present thenardite experiences a rapid partial transformation to decahydrate. Simultaneously with this transformation a rapid expansion of the sample was measured in situ.
\end{abstract}

T. A. Saidov $(\bowtie) \cdot$ L. Pel $~ K$ K. Kopinga

Department of Applied Physics, Eindhoven University of

Technology, PO Box 513, 5600 MB Eindhoven,

The Netherlands

e-mail: t.a.saidov@gmail.com
Keywords Stresses - Crystal growth from solutions . Salt damage $\cdot$ Weathering $\cdot$ Nuclear Magnetic Resonance

\section{Introduction}

Salt weathering is among the most common reasons behind the deterioration of porous building materials. The salt induced damages are caused by their accumulation and in turn their crystallization in the pores of materials due to cyclic drying/wetting and temperature changes. The pressure exerted by salt crystals also known as crystallization pressure might extend to the tensile strength of materials causing irreversible damages [1]. Since the cyclic changes are dependent on the weather conditions therefore durability of a material depends on the environmental conditions in which it is exposed [1-6]. To assess the durability of materials with respect to salt weathering often accelerated test are performed. Salt crystallization tests have been established and are based on the work of Correns in 1949 [7] on crystallization pressure, whereas weathering tests were already routinely used, e.g., de Thury in 1828 [8].

Sodium sulfate is among the most damaging salts for porous building materials. The phase diagram of sodium sulfate is presented in Fig. 1. This salt has four crystalline phases $[9,10]$ : thenardite $\left(\mathrm{Na}_{2} \mathrm{SO}_{4}\right.$, anhydrous salt), metastable phase III, decahydrate 


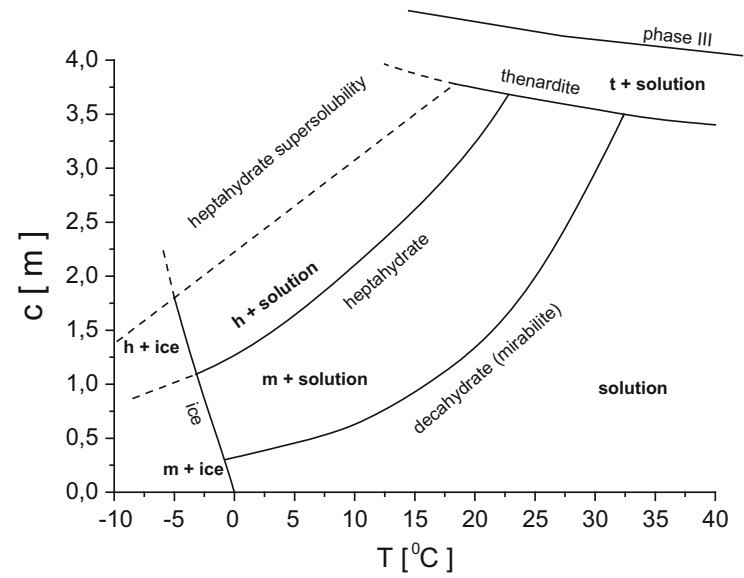

Fig. 1 The phase diagram of sodium sulfate. The equilibrium solubility is given for decahydrate $\left(\mathrm{Na}_{2} \mathrm{SO}_{4} \cdot 10 \mathrm{H}_{2} \mathrm{O}\right)$, thenardite $\left(\mathrm{Na}_{2} \mathrm{SO}_{4}\right)$, metastable anhydrous phase III, and the metastable form, i.e., heptahydrate $\left(\mathrm{Na}_{2} \mathrm{SO}_{4} \cdot 7 \mathrm{H}_{2} \mathrm{O}\right)$ together with heptahydrate supersolubility and ice line. The regions inbetween the solubility lines allow the coexistence of solution with certain crystalline phases. Where the alphabets $h, t, m$ used in Figure represent heptahydrate, thenardite, mirabilite (or decahydrate) respectively

(mirabilite, $\mathrm{Na}_{2} \mathrm{SO}_{4} \cdot 10 \mathrm{H}_{2} \mathrm{O}$ ) and thermodynamically metastable heptahydrate $\left(\mathrm{Na}_{2} \mathrm{SO}_{4} \cdot 7 \mathrm{H}_{2} \mathrm{O}\right)$. A wellknown test for assessing the salt weathering durability for sodium sulfate is DIN 52111 , which was developed in Germany in 1976 by Knofel et al. [11]. It consists of the immersion of a material to be tested in a solution saturated with sodium sulfate at $25^{\circ} \mathrm{C}$ (i.e. concentration is approx. $1.8 \mathrm{~mol} / \mathrm{kg}$ ) for $7 \mathrm{~h}$, then drying at $105{ }^{\circ} \mathrm{C}$ for another $7 \mathrm{~h}$ and then immersing again into the saturated solution. This procedure is repeated and weight loss of a sample (i.e., due to detachment of material usually in powdered form from the main piece of the sample) is measured per cycle, representing sample's resistance against sodium sulfate weathering.

As an example the results of DIN 52111 test for fired-clay brick are presented in Fig. 2. After 6 cycles, a complete disintegration of sample was observed for sodium sulfate solution. During cycling damage can both be induced by drying as the anhydrous form of sodium sulfate (thenardite) is crystallizing out or during rewetting of the dry sample, when crystallization of decahydrate is expected [2, 12-14] (see also phase diagram Fig. 1). In general, much more severe damage is reported during the wetting of the test specimens [2]. Damage caused by rewetting of

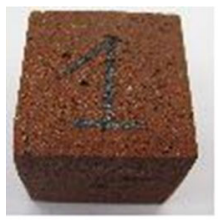

1

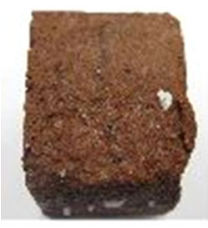

4

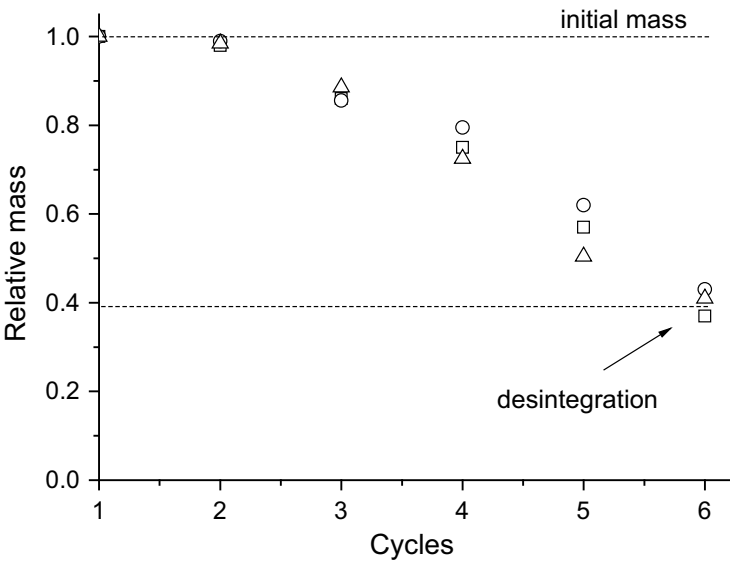

Fig. 2 The results of the DIN 52111 weathering test performed on three fired-clay brick cubes of $50 \times 50 \times 50 \mathrm{~mm}^{3}$. The relative masses of samples as a function of the number of cycles (bottom) and the corresponding photos of one of the samples after each cycle (top)

preliminary formed sodium sulfate thenardite has been discussed by many researches, e.g., [15]. However, a lack of direct observations of the phase of sodium sulfate crystals formed in porous materials precluded a definitive conclusion on the real damage scenario. To find out which crystallization pathway in sodium sulfate weathering is mostly responsible for damage in this study we have measured directly the concentration in a sample, indicating which crystal phase is formed, in combination with the expansion, indicating the damage potential.

We will first discuss the crystallization pressure in this weathering test. The test setup for simultaneously measuring the concentration in a sample and the expansion of the sample will be discussed next. Finally, we will discuss our experimental results. 


\section{Crystallization pressure during cycling}

In an accelerated weathering test a sample of a porous material undergoes cycles of drying with a salt solution and rewetting. Both processes can initiate crystallization, i.e., by drying the salt solution in the porous material or by transformation of a crystalline phase by rewetting. As a result of both processes a crystallization pressure can build up in the pores. One can distinguish between the crystallization pressure calculated from expansion of a porous material and/or from direct concentration measurements of salt solution in the sample. The crystallization pressure calculated from the measured salt solution concentration deals with the crystal growth and pressure build up on a microscopic scale, i.e., the growth of the crystal within the pore and the local pressure buildup. In this approach of the crystallization pressure the poromechanical properties of the material are not taken into account. In an alternative approach we can see the expansion, and resulting effects like cracking and disintegration of the material caused by pressure due to expansion, $P_{\mathrm{m}}$, which represents the pressure built up by the salt crystals in the material.

On a microscopic level according to Correns' thermodynamic model, the upper bound on the crystallization pressure, $P_{\mathrm{c}}$, can be presented as a function of supersaturation [15-23]:

$P_{\mathrm{c}}=\frac{R T}{V_{\mathrm{m}}} \ln \beta$ where $R$ is the gas constant, $T$ is the temperature, $V_{\mathrm{m}}$ is the molar volume of the crystal, $\beta=Q / K$ is the supersaturation, $Q=$ activity product, $K=$ equilibrium product. The supersaturation is concentration and temperature dependent and can be determined using the Pitzer parameterization of Steiger and Asmussen [2]. Correns' equation sets an upper bound on the crystallization pressure as it does not take into account curvature effects. Moreover, it also neglects the contribution of small crystals presented in large pores where they cannot exert pressure. These effects can be neglected for materials that have micron and higher average pore sizes [1,2], which is indeed the case, see Table 1.

The macroscopic crystallization pressure by expansion can be evaluated by analyzing the actual expansion of a sample due to salt crystallization. Assuming the crystals are uniformly distributed within the porous materials and there is no preferred direction of crystal growth in the pores, according to thermoporoelasticity [18], the crystallization pressure by expansion, $P_{\mathrm{m}}$, in the isothermal case is given by:

$P_{\mathrm{m}}=\int \frac{3 K}{b \phi} \mathrm{d} \varepsilon$

where $P_{\mathrm{m}}$ is the pore pressure exerted by confined crystals in the porous material, $\varepsilon(\mathrm{m})$ is the expansion of a sample due to salt crystallization, $K(\mathrm{~Pa})$ is the bulk modulus, $b$ is the Biot-coefficient and $\phi$ $(0<\phi<1)$ is the pore filling coefficient. This pore

Table 1 Poromechanical properties of the materials used in the study [13, 24] and pore filling coefficients after the first rewetting as, calculated using Eqs. (3)-(10)

\begin{tabular}{llll}
\hline & Fired-clay brick & Indiana limestone & Cordova limestone \\
\hline Porosity, $\rho_{\text {pore }}$ & 0.35 & 0.12 & 0.16 \\
Compressibility $[1 /(\mathrm{GPa})]$ & 0.393 & 0.055 & 0.091 \\
Mean pore size $(\mu \mathrm{m})$ & 40 & 60 & 0.6 and 50 \\
Biot-coefficient, $b$ & 0.887 & 0.857 & 0.759 \\
Bulk modulus, $K(\mathrm{GPa})$ & 2.54 & 18.2 & 11 \\
Initial pore volume, $V_{0}\left(\mathrm{~cm}^{3}\right)$ & 1.1 & 0.38 & 0.5 \\
Pore filling by thenardite before first injection, $\phi_{\mathrm{t}}$ & 0.13 & 0.14 & 0.14 \\
Actual pore filling by decahydrate after first injection, $\phi_{\mathrm{d}}$ & 0.159 & 0.195 & 0.232 \\
Maximal transformation ratio after first injection $(\%)$ & 35 & 100 & 77 \\
Measured transformation ratio after first injection $(\%)$ & 31 & 36 & 27 \\
\hline
\end{tabular}


filling coefficient can be directly evaluated from the concentration (see the "Appendix").

\section{Experimental set-up}

To find out which crystallization pathway in sodium sulfate weathering is mostly responsible for damage we have performed a weathering experiment in Nuclear Magnetic Resonance (NMR) setup. We use NMR in combination with an optical displacement sensor for measuring both concentration of the solution in the samples, and the expansion caused by crystallization during the weathering. The experimental setup is presented in Fig. 3. The NMR used in this study makes use of an electromagnet generating a magnetic field of $0.78 \mathrm{~T}$, corresponding to a resonance frequency of $33.2 \mathrm{MHz}$ for ${ }^{1} \mathrm{H}$ and $8.78 \mathrm{MHz}$ for ${ }^{23} \mathrm{Na}$. Using a specially-designed RF circuit the resonance frequency of RF-coil the insert can be changed from 33.2 to $8.78 \mathrm{MHz}$, giving the possibility to quasi-simultaneously measure both the $\mathrm{H}$ and $\mathrm{Na}$ signal [17]. To reduce the effects of variation of the dielectric permittivity by a changing moisture and salt

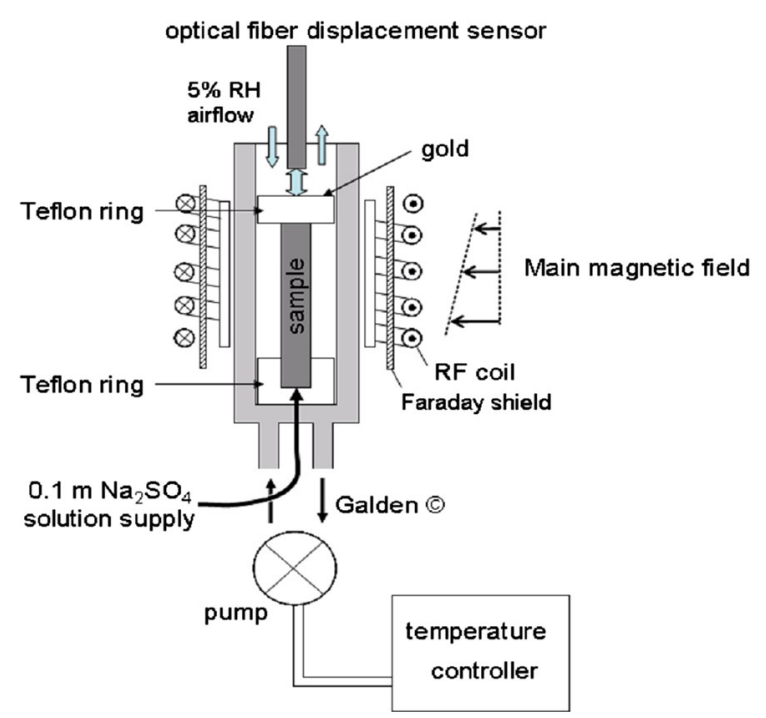

Fig. 3 A schematic representation of the experimental setup for simultaneously measuring both the concentration in a sample with NMR and the expansion of the sample with an optical displacement sensor. The cylindrical sample of $10 \mathrm{~mm}$ diameter and length of $50 \mathrm{~mm}$ is kept in a temperature controlled sample holder. Using a 5\% RH airflow of $0.21 / \mathrm{min}$ the sample can be dried whereas the sample can be rewetted by a tube from the bottom with a $0.1 \mathrm{~m}$ sodium sulfate solution content in the sample, a Faraday shield was placed between the tuned circuit of the probe head and the sample [17, 19]. In this setup we use a fixed gradient of $0.15 \mathrm{~T} / \mathrm{m}$. As a result the average $\mathrm{H}$ and $\mathrm{Na}$ content is measured over a slice of the order of $3 \mathrm{~mm}$ thickness. During these experiment the sample was not moved. The spin-echo time was chosen in such a way that no signal from $\mathrm{Na}$ and $\mathrm{H}$ nuclei incorporated into the crystals was obtained. Hence the measured signal for $\mathrm{H}$ can be directly related to moisture content $\left(\mathrm{m}^{3} \mathrm{~m}^{-3}\right)$ in the sample. The combination of both the $\mathrm{H}$ and $\mathrm{Na}$ signals determines the $\mathrm{Na}$ concentration $(\mathrm{m}=\mathrm{mol} /$ $\mathrm{kg}$ ) of the solution in the sample, providing the possibility of non-destructively measuring the $\mathrm{Na}$ concentration in a sample. Since NMR signal intensity is related to temperature of the sample and in order to maintain the sample temperature constant a commercially available fluid named as Galden (a liquid that does not contain hydrogen nuclei) was continuously circulated into the walls of insert surrounding the sample. A more detailed explanation of the NMR setup can be found in Ref. [14, 16, 17].

In our experiments a cylindrical shaped sample with diameter of $10 \mathrm{~mm}$ and a height of $50 \mathrm{~mm}$ was centered with Teflon rings, which allows an almost frictionless expansion of sample. A fiber optic displacement sensor was used to measure the length of the sample. For this purpose, the Teflon ring on top of the sample was coated with gold to act as an optical reflector for the displacement sensor. The resolution of the displacement sensor was determined by measuring the expansion of aluminum and was found to be of the order of $\pm 1 \mu \mathrm{m}$.

Due to experimental limitations of the NMR setup, the sample can only be temperature controlled over a limited temperature range up to $40{ }^{\circ} \mathrm{C}$, so we have used an adapted weathering cycle. Using the temperature control system, the temperature was fixed at $22{ }^{\circ} \mathrm{C}$, i.e., close to the room temperature. Initially the sample was vacuum saturated with a $3 \mathrm{~m}(\mathrm{~mol} / \mathrm{kg})$ sodium sulfate solution at a temperature of $T=40^{\circ} \mathrm{C}$ and slowly cooled down to $22{ }^{\circ} \mathrm{C}$, after which the drying conditions were applied. The drying was induced by maintaining a $0.2 \mathrm{l} / \mathrm{min} 5 \% \mathrm{RH}$ airflow over the top of the setup/sample. The spacing between the Teflon rings and the sample holder was found large enough to let the sample dry. After drying the sample to about $25 \%$ of its initial moisture content, it was rewetted from the bottom using a fixed amount i.e. 
$0.2 \mathrm{ml}$ of $0.1 \mathrm{~m} \mathrm{Na}_{2} \mathrm{SO}_{4}$ solution, to compensate the loss of salt due to its detachment from sample caused by efflorescence during drying cycle. The rewetting amount of $0.2 \mathrm{ml}$ was completely absorbed by the sample. We have chosen $25 \%$ of the initial moisture content to stay above the critical saturation point where the liquid film starts to break up, and to make sure to characterize the advection-diffusion process during drying using the Peclet number and the experiment can be represented in an efflorescence pathway diagram [22].

\section{Weathering within an NMR}

The weathering experiments in this study were performed on three porous materials, i.e., fired-clay brick, Cordova limestone and Indiana limestone. Both fired-clay brick and Indiana limestone have a unimodal pore size distribution, with a mean pore size of 40 and $60 \mu \mathrm{m}$ respectively, whereas Cordova limestone has a bimodal pore size distribution, with twopeaks indicating that two major pore sizes are present at 0.6 and 50 microns [13]. The properties of all three materials used in this study are e presented in Table 1.

\subsection{Cycle one}

Initially the samples were vacuum saturated with a $3 \mathrm{~m}$ sodium sulfate solution at $40{ }^{\circ} \mathrm{C}$ after which the samples were cooled down to $22{ }^{\circ} \mathrm{C}$. After cooling down to $22{ }^{\circ} \mathrm{C}$ the drying of samples was initiated by maintaining an air flow of 5\% RH over the sample. The measured variations in moisture saturation, concentration and the expansion of sample during wetting and drying cycles as a function of time are shown in Fig. 4. Initially the solution in sample is supersaturated with respect to decahydrate after that the sample is cooled down from $40{ }^{\circ} \mathrm{C}$, indicating that the porous substrate is not acting as a nucleation for decahydrate formation, as it was also found in the case of using powdered samples [21]. As soon as the drying starts (point $A$ in Fig. 4) the saturation and hence the water content decreases and the concentration of the sodium sulfate solution in the samples rises up to the thenardite concentration, indicating thenardite crystals are being formed in accordance with Ostwald's rule of successive crystallization [9]. As it can be seen that a small supersaturation in the order of $\sim 1.1$ is built up in the sample. From the moment that a supersaturation is built up an expansion of the sample can be observed, i.e., from approximately $2 \mu \mathrm{m}$ for fired-clay brick to $\sim 4 \mu \mathrm{m}$ for Cordova limestone.

To obtain more information on the salt transport during drying we have also plotted the same data in a so-called efflorescence pathway diagram (EPD) in Fig. 5 [21]. In an EPD, the total amount of dissolved sodium sulfate presented in the solution corresponding to $c \theta$ (in $\mathrm{mol} / \mathrm{kg}$ ) is plotted against the saturation $\mathrm{S}$. In such a diagram two limiting situations can be distinguished. During very slow drying, i.e., Peclet number $P e \ll 1$, the ions profiles remain homogeneous and for some time no crystallization occurs. The average sodium sulfate concentration slowly increases until the complete sample has reached the solubility of thenardite i.e., $3.4 \mathrm{~m}$. After this point any additional drying will result in crystallization. During very fast drying i.e., $P e \gg 1$ ions move along with the moisture to the top of the sample due to advection and a concentration peak builds up with a very small width. If the rate of crystallization is high enough, i.e., if there are enough nucleation sites at the top to form crystals, the average $\mathrm{Na}_{2} \mathrm{SO}_{4}$ concentration in the solution of the sample itself will remain almost constant nearly equal to the initial concentration.

As can be seen for all of these experiments $P e \ll 1$ in the initial drying, indicating diffusion is dominant. In this case we expect a homogenous crystallization throughout the sample causing the expansion of the material. Moreover, these EPDs reconfirm that thenardite is being formed in these samples.

When the saturation of samples dropped to about $25 \%$, the sample were rewetted slowly by injecting from the bottom with $0.2 \mathrm{ml}$ of $0.1 \mathrm{~m}$ of sodium sulfate solution. With this rewetting an immediate decrease in the concentration is observed. As can be seen in Fig. 4, the final concentration after rewetting is in between the equilibrium concentrations of decahydrate and thenardite. This indicates there is a partial transformation of thenardite to decahydrate. Indeed for the fixed amount of $0.2 \mathrm{ml}$ of $0.1 \mathrm{~m}$ of sodium sulfate solution used in these experiments, if there had been a complete transformation then in the case of the Indiana limestone all the water would have been taken up by the crystals. This will appear as a sudden decrease of moisture content in the system. Since the water from the solution is to be incorporated into the mirabilite. Indeed, this was partially observed in the 
Fig. 4 The measured saturation, concentration and expansion as a function of time for a fired-clay brick, b Cordova limestone and c Indiana limestone. Initially all sample are saturated $3.0 \mathrm{~m}$ sodium sulfate at $40{ }^{\circ} \mathrm{C}$, after which the samples are cooled down to $22{ }^{\circ} \mathrm{C}$ and the experiment is started. The dashed lines correspond to the saturation levels for the various crystalline phases. In the top figure, point $A$ corresponds to the start of the drying, $B$ ongoing drying, leading to formation of thenardite, $C$, $D, E$-re-wettings
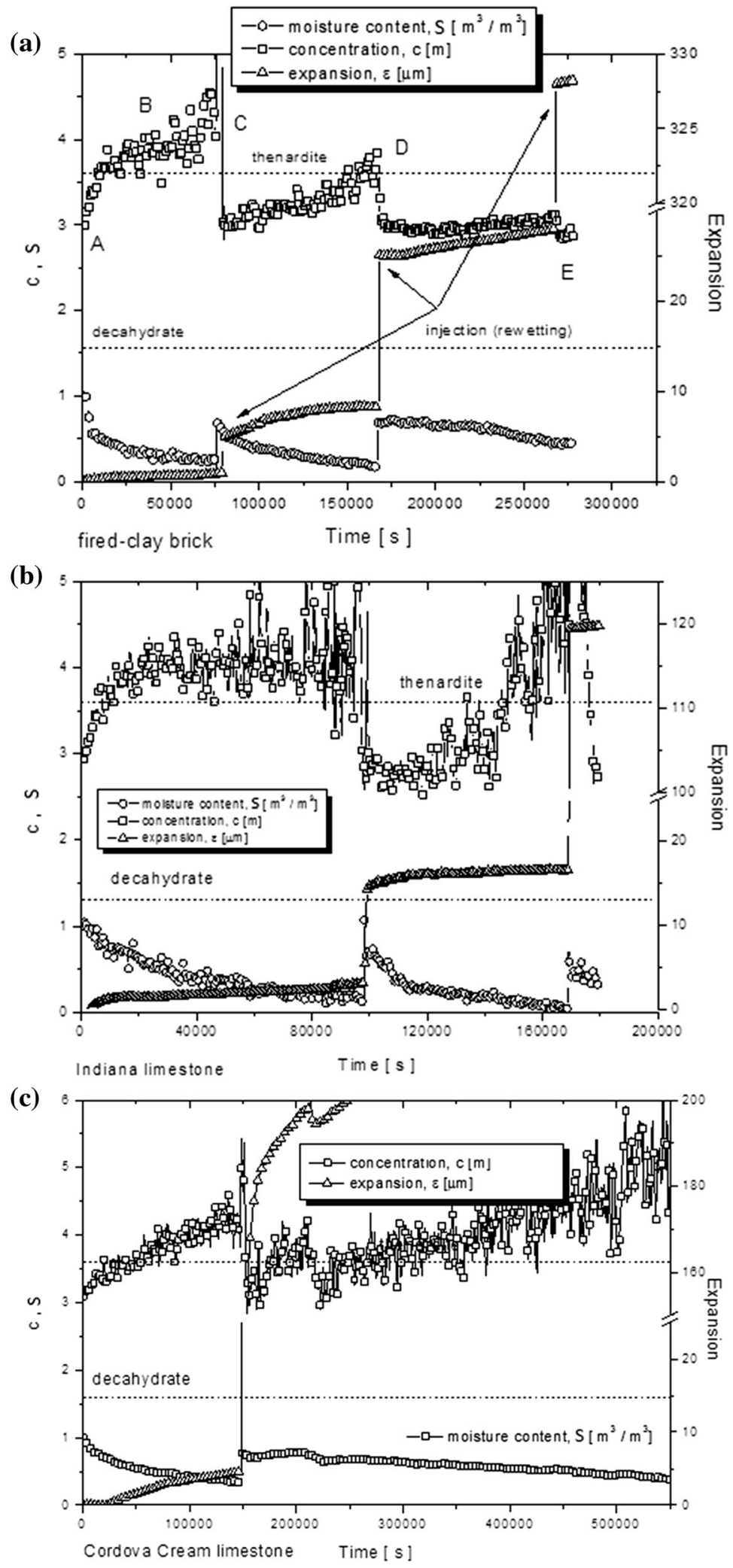
Fig. 5 Efflorescence pathway diagram for the drying part of the weathering cycles (see also Fig. 4). The total amount of dissolved salt in the solution, $c \theta$ (in $\mathrm{mol} / \mathrm{kg}$ ) is plotted against the saturation $S$. The two possible salt phases at $22{ }^{\circ} \mathrm{C}$ which can be formed are indicated by $c=3.6 \mathrm{~m}$ for thenardite and $c=1.6$ for decahydrate. Arrows show propagation of time and directions (dashed lines) that the crystallization process can follow, depending on actual $\mathrm{Pe}$ number. Horizontal dashed lines labeled by "start first cycle", "second" or "third cycle" indicate the theoretical levels, where each of cycles may start
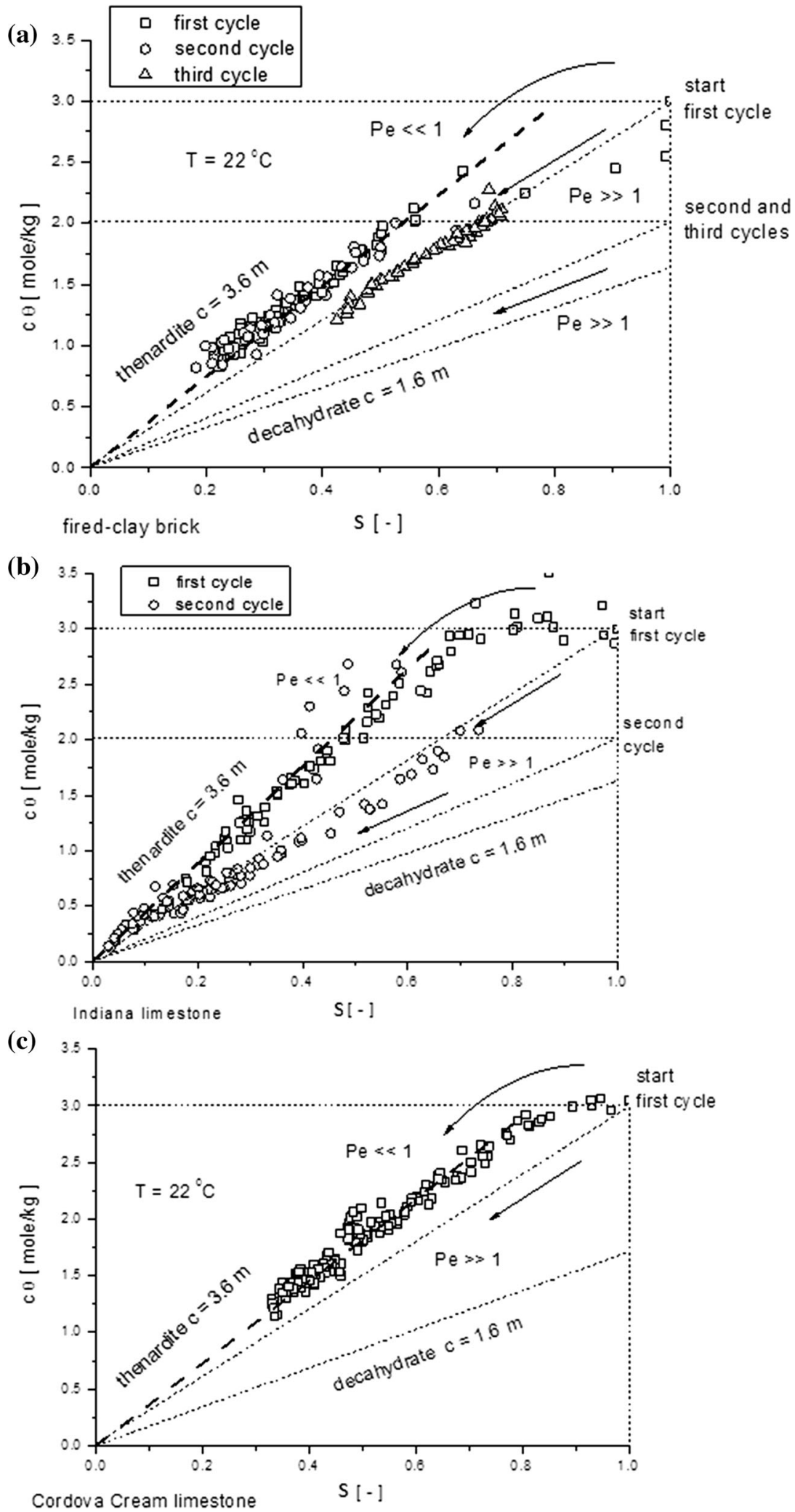
case of Indiana limestone. As can be seen from Fig. 4 that after first rewetting ( $\sim$ after $100,000 \mathrm{~s}$.) the saturation suddenly dropped from 1 to about 0.6. The partial transformation is most probably caused by the competition between thenardite dissolution and transformation rate. This will lead to a mixture of thenardite and decahydrate in the pores of a material as reported by Rodriguez-Navarro et al. [3]. Indeed from the initial amount of thenardite formed during drying and the measured concentration immediately after rewetting we can make an estimation of transformation ratio (for calculation see "Appendix") as given in Table 1. These measurements indicate that only up to about $30 \%$ of the thenardite is directly transformed into decahydrate.

Because of the competition between dissolution of thenardite and formation of decahydrate the solution remains highly supersaturated with respect to decahydrate. Therefore, a high crystallization pressure is built up as soon as the sample is rewetted and a rapid expansion of the sample is observed. Based on the measured concentration we can estimate the crystallization pressure which is plotted in Fig. 6. As can be seen due to rewetting the crystallization pressure increases by $200-300 \%$.

Using the measured expansion we can get an indication of the pressure $P_{\mathrm{m}}$. In Fig. 6, the pressures inferred from the expansion calculated before and

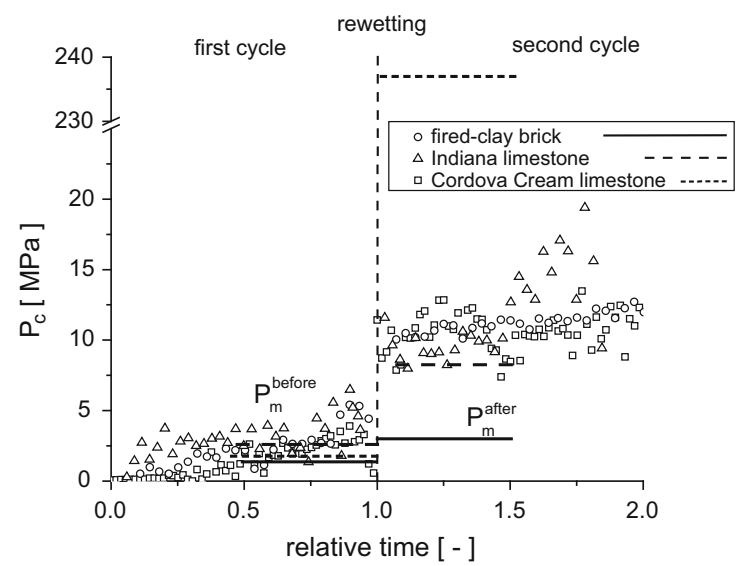

Fig. 6 The calculated crystallization pressures, $P_{\mathrm{c}}$, by solution concentration and by expansion as a function of the relative time with respect to the moment of rewetting (cycles, triangles and squares). Horizontal lines present calculated pressure by expansion, $P_{\mathrm{m}}$, just before and after rewetting. Time is given as a relative value in order to scale all the processes with respect to the event of rewetting (time $=1$ ) after rewetting are presented as horizontal dashed line. As can be seen after rewetting $P_{\mathrm{m}} \leq P_{\mathrm{c}}$ for both firedclay brick and Indiana limestone, whereas for Cordova limestone $P_{\mathrm{m}}>P_{\mathrm{c}}$ indicating disintegration. When the poromechanical pressure is found to exceed Correns' value it is attributed to damage as it was confirmed by visual inspection of the samples (see Fig. 7). For Indiana limestone $P_{\mathrm{m}} \approx P_{\mathrm{c}}$ whereas for fired-clay brick $P_{\mathrm{m}} \leq P_{\mathrm{c}}$. These observations agreed well with our previous findings on the estimation of pressures during crystallization of decahydrate in the same porous materials induced by cooling of the sealed samples without drying [14].

\subsection{Cycles two and three}

After the first rewetting, the drying is continued (second cycle, $C-D$ in Fig. 4) and a decrease in saturation and an increase in concentration up to the thenardite solubility is observed, i.e., the second cycle. At the same time an expansion of the material can be observed. Again we have plotted the drying process in the form of an EPD diagrams as presented in Fig. 5. In this case we observed that in the second cycle $P e \gg 1$, indicating inhomogeneous salt concentration profiles. This change in $P e$ is caused by partial transformation of thenardite to decahydrate, changing the morphology of the remaining porosity available for moisture transport by drying. Hence, the measured concentration can only be seen as an indication and there will probably still be a mixture of thenardite and decahydrate in the sample.

When the saturation in this cycle has decreased to $25 \%$, a second injection of $0.2 \mathrm{ml}$ sodium sulfate solution of $0.1 \mathrm{~m}$ was made ( $D$ in Fig. 4 ) and again rapid decrease of concentration, indicating a transformation to decahydrate, is observed with a simultaneous expansion of the sample. Since the solubility of dehydrate is lower therefore a higher supersaturation will be created leading to a higher crystallization pressure. During this time the a larger expansion is observed, e.g., for fired-clay brick approx. 19 versus $4 \mu \mathrm{m}$ in the first injection. This is probably due to the inhomogeneous drying and therefore the crystallization predominantly occurring near the drying surface resulting in a higher pore filling. This local higher pore filling near the surface will give a higher expansion when thenardite is transformed to decahydrate. After the second cycle a crack is observed in the Indiana 


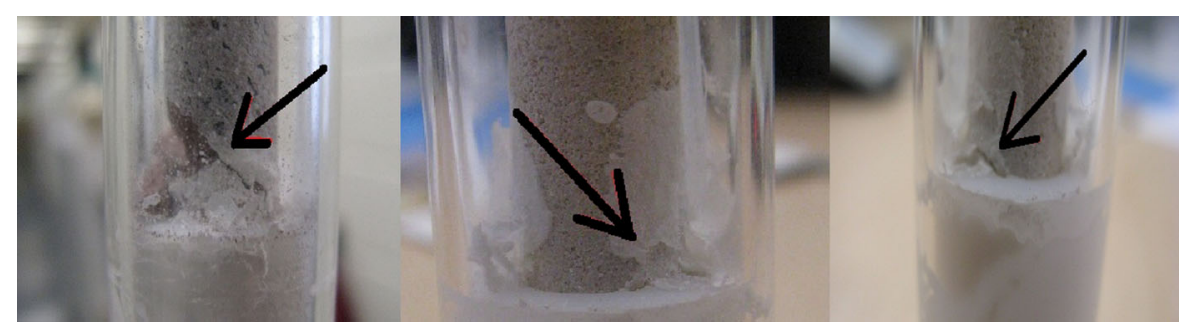

Fig. 7 Pictures of the sample at the end of the accelerated weathering test within the NMR setup: from left to right: fired-clay brick, Indiana limestone and Cordova limestone. The visual observable cracks are indicated

limestone and the experiment was only continued for the fired-clay brick, see Fig. 7.

In the third cycle again when the saturation was decreased to $25 \%$ due to drying for the fired-clay brick, a third injection of $0.2 \mathrm{ml}$ sodium sulfate solution of $0.1 \mathrm{~m}$ was given. In this case after the injection an expansion of $320 \mu \mathrm{m}$ was observed ( $\mathrm{E}$ in Fig. 4 top), indicating the disintegration of the firedclay brick sample due to the formation of cracks.

\section{Conclusions}

During the drying at $22{ }^{\circ} \mathrm{C}$ of porous materials initially saturated with sodium sulfate solution thenardite is formed. With rewetting of the thenardite, an instant but partial transformation to decahydrate occurs. After the transformation the pores are filled with a mixture of thenardite/decahydrate. As a result of this partial transformation a constant supersaturation is maintained in the sample, yielding a relatively high crystallization pressure. The absence of direct crystallization of decahydrate from sodium sulfate solution during drying but rather the instant transformation from thenardite by rewetting is the cause of expansion and can lead to disintegration of materials. Therefore, thenardite-to-decahydrate transformation by rewetting is the main cause of damage by weathering of materials contaminated with sodium sulfate solutions within the temperature range between 22 and $25{ }^{\circ} \mathrm{C}$. Among the materials tested fired-clay brick is the most sustainable material under cyclic conditions whereas Indiana limestone shows damage after the second cycle. For Cordova limestone it is observed that already at the first rewetting the formation of dehydrate results in damage. At present we did not observe a direct correlation with the measured poromechenical properties of the material used in this study (see also Table 1). In future study, we will focus on investigating the weathering in the region up to $22{ }^{\circ} \mathrm{C}$, where also heptahydrate can be formed.

Since heptahydrate can be formed at lower temperatures, therefore, the investigation of the weathering phenomenon in the lower temperature range below $22{ }^{\circ} \mathrm{C}$ will be part of the future study.

Acknowledgements This research was supported by the Dutch Technology Foundation (STW), Project 06752: Salt Weathering of porous building materials.

\section{Appendix: Calculation of salt mixture content during drying}

Let us estimate the pore filling coefficient, i.e., the relative volume occupied by salts (thenardite and/or decahydrate) with respect to the pore volume (volume of the sample times porosity), $V_{0}$, initially filled with a solution. The pore filling coefficient of a particular salt varies from 0 -no filling, to 1 -complete filling and can be presented in the form:

$\phi_{\mathrm{t}}=\frac{V^{\mathrm{t}}}{V_{0}}$

$\phi_{\mathrm{d}}=\frac{V^{\mathrm{d}}}{V_{0}} ;$

where $\phi_{\mathrm{t}}$ and $\phi_{\mathrm{d}}$ are the pore filling coefficients, $V^{\mathrm{t}}$ and $V^{\mathrm{d}}$ are the crystal volumes of thenardite and decahydrate respectively. Then, the crystal volume of thenardite formed is $V^{\mathrm{t}}=V_{\mathrm{m}}^{\mathrm{t}} \Delta n$, where $V_{\mathrm{m}}^{\mathrm{t}}=53$ $\mathrm{cm}^{3} / \mathrm{mol}$ is the molar volume of thenardite and $\Delta n$ is the amount (in moles) of thenardite precipitated by drying. If by rewetting all thenardite transforms to 
decahydrate, then the volume of decahydrate is $V^{\mathrm{d}}=V_{\mathrm{m}}^{\mathrm{d}} \Delta n$, where $V_{\mathrm{m}}^{\mathrm{d}}=220 \mathrm{~cm}^{3} / \mathrm{mol}$.

The amount of precipitated thenardite by drying can be found from the difference between initial, $n_{0}$, and actual, $n$, amount of sodium sulfate in a solution:

$$
\Delta n=n_{0}-n=\frac{m_{0}^{\text {salt }}-m^{\text {salt }}}{M_{\text {salt }}}
$$

where $m_{0}^{\text {salt }}$ and $m^{\text {salt }}$ are the initial and actual masses of thenardite in a solution. The mass of the solution, $m^{\text {sol }}$, can be presented as a sum of the mass of water, $m^{\mathrm{w}}$, and of the sodium sulfate dissolved in a solution, $m^{\text {salt }}$ :

$$
m^{\text {sol }}=m^{\mathrm{w}}+m^{\text {salt }}=n^{\mathrm{w}} M_{\mathrm{w}}+n^{\text {salt }} M_{\text {salt }} ;
$$

where $n^{\mathrm{w}}$ and $n^{\text {salt }}$ are the actual amounts (in moles) of water and salt in the solution respectively, $M_{\mathrm{w}}$ and $M_{\text {salt }}$ are the molar masses of water and salt (in our case respectively $18 \mathrm{~g} / \mathrm{mol}$ and $142.04 \mathrm{~g} / \mathrm{mol}$ - thenardite). The concentration of a solution during the drying is:

$c=\frac{n^{\text {salt }}}{m^{\mathrm{w}}}=\frac{n^{\mathrm{salt}}}{\theta m_{0}^{\mathrm{w}}}$

where $\theta$ is the moisture content and $m_{0}^{\mathrm{w}}$ is the initial mass of water in a solution. In the case, $\theta=1$, when $n^{\text {salt }}$ is equal to initial amount of salt in the solution (i.e., $n^{\text {salt }}=n_{0}^{\text {salt }}$ ), from Eq. (5) one will obtain the initial concentration of the solution, $c_{0}$. Therefore, the initial mass of water can be found from Eqs. (6) and (7) by the expression:

$m_{0}^{\mathrm{w}}=\frac{m_{0}^{\mathrm{sol}}}{\left(1+c_{0} M_{\text {salt }}\right)} ;$

where the mass of initial solution, $m_{0}^{\text {sol }}=V_{0} \rho_{0}^{\text {sol }}$, and the density of the initial sodium sulfate solution of $3 \mathrm{~m}$ is $\rho_{0}^{\mathrm{sol}}=1.34 \mathrm{~g} / \mathrm{cm}^{3}$, and inner pore volume is a sample volume times porosity, hence $V_{0}=\rho_{\text {pore }}$ $V_{\text {sample }}$, where $V_{\text {sample }}=3.14 \mathrm{~cm}^{3}$.

Combining Eqs. (5)-(8), we can find the amount of thenardite that precipitated during the drying:

$$
\Delta n=\rho_{\text {pore }} V_{\text {sample }} \rho^{\text {sol }}\left(\frac{c_{0}-c \theta}{1+c_{0} M_{\text {salt }}}\right) ;
$$

where $c$ is the actual concentration of a solution and is measured by an NMR and presented in Fig. 4.

In the case, where not all thenardite is transformed to decahydrate, the concentration of a solution is expected to be between of the solubility of thenardite and decahydrate. Then the pore filling ratio of actually formed decahydrate (under assumption of homogenous distribution of a salt in the sample, i.e., $P e \ll 1$ ) can be in first order estimated by the relation of actual concentration of a solution and solubility concentrations of thenardite and decahydrate:

$$
\phi_{\mathrm{d}}^{\mathrm{act}} \approx\left(1-\frac{c-c_{\mathrm{s}}^{\mathrm{d}}}{c_{\mathrm{s}}^{\mathrm{t}}-c_{\mathrm{s}}^{\mathrm{d}}}\right) \phi_{\mathrm{d}} ;
$$

In the case of all thenardite transformed to decahydrate, we return to initial expression (3).

The calculated initial pore volume, $V_{0}$, and pore filling coefficients $\phi_{\mathrm{t}}$ and $\phi_{\mathrm{d}}^{\text {act }}$ are given in Table 1 .

\section{References}

1. Scherer GW (2004) Stress from crystallization of salt. Cem Concr Res 34:1613-1624

2. Steiger M, Asmussen S (2008) Crystallization of sodium sulfate phases in porous materials: the phase diagram $\mathrm{Na}_{2}$ $\mathrm{SO}_{4}-\mathrm{H}_{2} \mathrm{O}$ and the generation of stress. Geochim Cosmochim Acta 72:4291-4306

3. Rodriguez-Navarro C, Doehne E, Sebastian E (2000) How does sodium sulfate crystalize? Implications for the decay and testing of building materials. Cem Concr Res 30:1527-1534

4. Doehne E (1982) An unusual case of ground water sulphate attack on concrete. Cem Concr Res 12:633-639

5. Yoshida N, Matsunami Y, Nagayama M (2012) Sodium sulfate weathering in the residential concrete foundation, Concrete under severe conditions. CRC Press, Boca Raton, pp 75-83. ISBN 978-0-415-59316-8

6. Haynes H, O'Neill R, Neff M, Mehta PK (2008) Weathering distress on concrete exposed to sodium sulfate environment. Mater J 10:35-43

7. Correns CW (1949) Growth and dissolution of crystals under linear pressure. Discuss Faraday Soc 5:267-271

8. de Thury H (1828) Sur le procédé proposé par M. Brard pour reconnaître immediatement les pierres qui ne peuvent pas résister à la gelée, et que l'on désigne ordinairement par les noms de pierres gelives ou pierres gelisses. Ann Chimie Phys 38:160-192

9. Hartley H, Jones BM, Hutchinson GA (1908) The spontaneous Crystallization of Sodium sulfate solutions. J Chem Soc 93:825-833

10. Gans W (1979) Thermodynamic stability of sodium sulfate heptahydrate. Z Phys Chem Neue Folge 111:39-46

11. Knofel DK, Hoffmann D, Snethlage R (1982) Physicochemical weathering reactions as a formulary for timelapsing ageing tests. Mater Struct 20:127-145

12. Rodriguez-Navarro C, Doehne E (1999) Damage in porous media due to salt crystallization. Earth Surf Process Landf 24:19-209

13. Saidov TA, Pel L, van der Heijden GHA (2015) Crystallization of sodium sulfate in porous media by drying at a constant temperature. Int J Heat Mass Transf 83:621-628 
14. Saidov TA, Pel L, Kopinga K (2015) Crystallization pressure of sodium sulfate heptahydrate. J Cryst Growth Des 15(5):2087-2093

15. Tsui N, Flatt RJ, Scherer GWJ (2003) Crystallization damage by sodium sulfate. Cult Herit 4:109-115

16. Rijniers LA, Huinink HP, Pel L, Kopinga K (2005) Experimental evidence of crystallization pressure inside porous media. Phys Rev Lett 94:075503

17. Rijniers LA (2004) Salt crystallization in porous materials: an NMR study. PhD thesis, Eindhoven University of Technology, Eindhoven

18. Coussy O (2006) Deformation and stress from in-pore drying-induced crystallization of salt. J Mech Phys Solids 54:1517-1547

19. Pel L, Kopinga K, Kaasschieter EF (2000) Saline absorption in calcium silicate brick observed by NMR scanning. J Phys D Appl Phys 33:1380-1385
20. Kopinga K, Pel L (1994) One dimensional scanning of moisture in porous materials with NMR. Rev Sci Instrum 65:3673-3681

21. Saidov TA, Pel L, Espinosa-Marzal RM (2012) G.W. Scherer, Nucleation of sodium sulfate heptahydrate on mineral substrates studied by nuclear magnetic resonance. J Cryst Growth 338:166-169

22. Pel L, Huinink H, Kopinga K, van Hees RPJ, Adan OCG (2004) Efflorescence pathway diagram: understanding salt weathering. Constr Build Mater 18:309-313

23. Flatt RJ, Steiger M, Scherer GW (2007) A commented translation of the paper by C.W. Correns and W. Steinborn on crystallization pressure. Environ Geol 52(2):187-203

24. Saidov T (2012) Sodium sulfate heptahydrate in weathering phenomena of porous materials. Ph.D. thesis, Eindhoven University of Technology, Oct 2012 